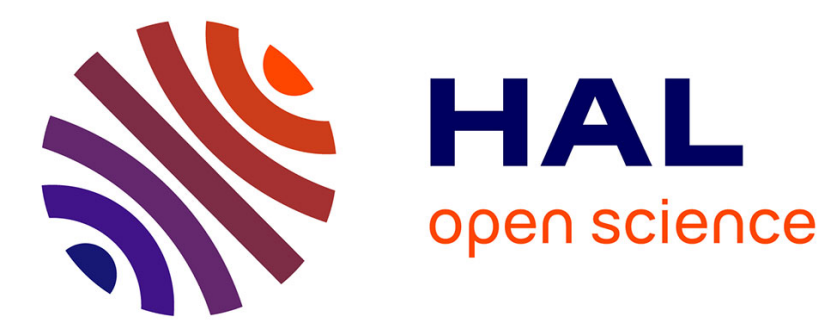

\title{
Using the Law as a 'Harmonious Weapon': The Ambiguities of Legal Activism in Favour of Migrant Workers in China
}

Chloé Froissart

\section{- To cite this version:}

Chloé Froissart. Using the Law as a 'Harmonious Weapon': The Ambiguities of Legal Activism in Favour of Migrant Workers in China. Journal of Civil Society, 2014, 10, pp.255 - 272. 10.1080/17448689.2014.941086 . hal-03168621

\section{HAL Id: hal-03168621 \\ https://hal.science/hal-03168621}

Submitted on 6 Apr 2021

HAL is a multi-disciplinary open access archive for the deposit and dissemination of scientific research documents, whether they are published or not. The documents may come from teaching and research institutions in France or abroad, or from public or private research centers.
L'archive ouverte pluridisciplinaire HAL, est destinée au dépôt et à la diffusion de documents scientifiques de niveau recherche, publiés ou non, émanant des établissements d'enseignement et de recherche français ou étrangers, des laboratoires publics ou privés. 
This article was downloaded by: [Chloe Froissart]

On: 05 September 2014, At: 09:26

Publisher: Routledge

Informa Ltd Registered in England and Wales Registered Number: 1072954 Registered

office: Mortimer House, 37-41 Mortimer Street, London W1T 3J H, UK

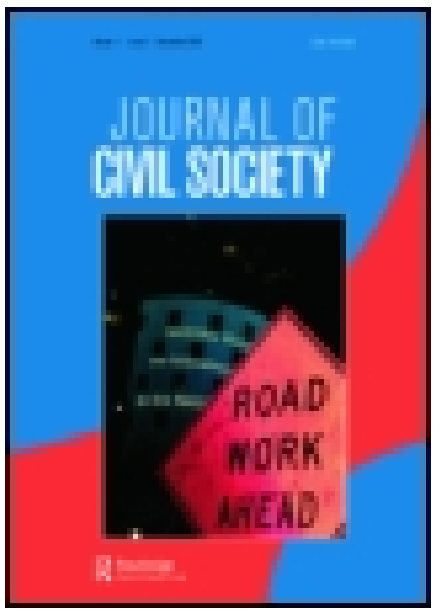

\title{
J ournal of Civil Society
}

Publication details, including instructions for authors and subscription information:

http:/ / www. tandfonline.com/loi/ rcis20

\section{Using the Law as a 'Harmonious Weapon': The Ambiguities of Legal Activism in Favour of Migrant Workers in China}

\author{
Chloe Froissart $^{a}$ \\ a French Centre for Research on Contemporary China (CEFC), \\ Wanchai, Hong Kong \\ Published online: 22 Aug 2014.
}

To cite this article: Chloe Froissart (2014): Using the Law as a 'Harmonious Weapon': The Ambiguities of Legal Activism in Favour of Migrant Workers in China, J ournal of Civil Society, DOI: 10.1080/17448689.2014.941086

To link to this article: http:// dx.doi.org/ 10.1080/ 17448689.2014.941086

\section{PLEASE SCROLL DOWN FOR ARTICLE}

Taylor \& Francis makes every effort to ensure the accuracy of all the information (the "Content") contained in the publications on our platform. However, Taylor \& Francis, our agents, and our licensors make no representations or warranties whatsoever as to the accuracy, completeness, or suitability for any purpose of the Content. Any opinions and views expressed in this publication are the opinions and views of the authors, and are not the views of or endorsed by Taylor \& Francis. The accuracy of the Content should not be relied upon and should be independently verified with primary sources of information. Taylor and Francis shall not be liable for any losses, actions, claims, proceedings, demands, costs, expenses, damages, and other liabilities whatsoever or howsoever caused arising directly or indirectly in connection with, in relation to or arising out of the use of the Content.

This article may be used for research, teaching, and private study purposes. Any substantial or systematic reproduction, redistribution, reselling, loan, sub-licensing, systematic supply, or distribution in any form to anyone is expressly forbidden. Terms \& Conditions of access and use can be found at http://www.tandfonline.com/page/termsand-conditions 


\title{
Using the Law as a 'Harmonious Weapon': The Ambiguities of Legal Activism in Favour of Migrant Workers in China
}

\author{
CHLOE FROISSART \\ French Centre for Research on Contemporary China (CEFC), Wanchai, Hong Kong
}

\begin{abstract}
Legal mobilization has spread in China over the past 20 years and is generally considered by both activists and scholars as a way to advance democracy and rule of law. Focusing on the mobilization in favour of migrant workers and on politically moderate practices, which are both more frequent and widely held as more successful, I argue to the contrary that resistance and reproduction of political domination are mutually constitutive. Public interest litigation and administrative litigation appear as new forms of political participation that constitute an internal regulation to the authoritarian regime, thus contributing to explain the regime's capacity to adapt and its durability. This article also accounts for new strategies developed by some lawyers that shun the courts and use law to 'empower civil society' and that thus do not contribute to structural reproduction. Though activists are struggling to turn their strategies into more institutionalized practices, they remain an ad hoc mechanism of internal control.
\end{abstract}

Key Words: Legal activism, rights lawyers, civil society, migrant workers, regime change, China

\section{Introduction}

Many studies on Chinese law have shown that the law is a contested resource between state and society. Whereas the Party-State uses the law as a way to bolster its ruling capacity and reassert its domination, an increasing number of citizens, encouraged by activist legal professionals, have resorted to law to advance their rights and curb political and economic power.

Since the crackdown on the 1989 democratic movement, a growing number of activists have indeed seen law as the new battlefield between state and society, where the political struggle to advance the rule of law and democracy could be pursued the most effectively

Correspondence Address: Chloe Froissart, CEFC 20/F Wanchai Central Building, 89 Lockhard Road, Wanchai, Hong Kong. Email: chloefroissart@gmail.com

(C) 2014 Taylor \& Francis 
(Pils, 2011; Teng, 2009). Legal mobilization is thus seen as a way to do politics by means other than overt political confrontation (Diamant et al., 2005), which would necessarily be doomed to be suppressed and hence to failure. Legal activists ground their action on a technical-apparently apolitical-soil and frame it in terms of values professed by the Chinese Communist Party (CCP), claiming to help it govern according to the law and advance the socialist rule of law.

However, the recent trial of Xu Zhiyong, ${ }^{1}$ a renowned rights defence lawyer dedicated to defending Chinese citizens' constitutional rights to personal security, freedom of belief, and equal access to education, reminds us that taking the Party at its word and taking the law seriously are still deemed an intolerable challenge to the Party's authority. An overtly political use of law, characterized by reference to higher legal principles combined with social mobilization, appears more often than not to be mere sacrifice and counterproductive action. ${ }^{2}$ Most rights defence lawyers thus tend to use law as a 'harmonious weapon' and try to strike a balance between defiance and acceptance of the regime constraints. Their action always presents a more or less direct challenge to the government and/or party authority (Pils, 2011) in the sense that it contests the existing social order, seeks to include vulnerable groups by disentangling the interests of economic and political elites, exposes authorities' misdeeds and failure to comply with their duty, and seeks to foster long-term structural change. At the same time, such actions try to engage the state and make the most of the de facto pluralistic nature of China's current one-party regime (Fu \& Cullen, 2008). They bring pressure to bear on authorities and force them to make concessions by resorting to lobbying and/or social and media mobilization. But they do so with and within the state, exploiting gaps and conflicting interests among the ruling elite.

Unlike radical lawyers who refuse to work within the constraints of the regime, such moderate lawyers, who work within the system while remaining critical of it and who try to compensate for its weakness by exerting political pressure or relying on political allies, are widely held to be the 'most successful ones' (Fu \& Cullen, 2008). ${ }^{3}$ A prevailing view among both Chinese legal activists and scholars who study them is indeed that their action, which usually takes the form of public interest litigations (PILs) or administrative litigations (ALs), is the most effective in protecting their clients' interests as well as advancing the cause of democracy and rule of law. Departing from a transitional perspective to emphasize regime hybridism (see, e.g. Dabène et al., 2008), I contend that growing opportunities for ordinary Chinese citizens to make their claims and assert their rights provide evidence of the expansion of a space for political participation within the authoritarian regime that does not threaten it but should rather be interpreted as being an integral part of its actual mode of operation.

Following Lazarus-Black and Hirsh (1994), I propose in this article to understand resistance and reproduction of political domination as mutually constitutive. Focusing on mobilization in favour of migrant workers, I seek to highlight how political constraints and limitations that legal activists impose on their actions make the law an ambivalent weapon in collective action, regardless of the intent of the social actors that is nonetheless impossible to assess. Relying on in-depth interviews with legal activists conducted between 2010 and 2013 as well as primary sources, Chinese press clippings and online documents, I examine in detail one case of PIL as well as a series of successful cases of ALs in order to document and analyse an inherently ambivalent, contradictory process. Underlining both their possibilities and limits, I argue that so-called efficient 
legal actions have become a new form of political participation within the system that together contests and reproduces mechanisms of political domination. Legal mobilization that attempts to play by the system at the same time plays for the system, and using the law as a harmonious weapon ends up at some point paying tribute to the Party's 'harmonioussociety' project. It creates an internal regulation within the authoritarian regime that compensates for the lack of electoral democracy and rule of law, thus hindering their development rather than fostering it. This internal regulation is a dynamic process that creates ad hoc checks and balances to the most pervasive abuses and at the same time constantly requires the Party to adapt. The process contributes to explaining the regime's durability.

However, as recalled by McCann (1994), the role of law in sustaining traditional hierarchies, and hence in structuring potential strategies of resistance, varies significantly depending on the sites of contention. 'Efforts to create and give meaning to norms ( . . ) often and importantly occur outside formal legal institutions such as courts' (p. 8). Hope indeed emerges as some legal activists have decided to turn away from the courts and use the law to 'empower civil society'. This kind of non-institutionalized legal mobilization, as shown by the last case study dedicated to the rise of autonomous forms of collective bargaining, embodies an interesting example of moderate/effective action that disentangles contestation from participation in authoritarian governance and does not reproduce mechanisms of political domination. Nevertheless, as this kind of mobilization still struggles for its institutionalization through legal protection of workers' representatives independent from official trade unions, it is for now reduced to playing the role of an ad hoc regulation within the authoritarian regime and hence to remaining a component contributing to the regime's flexibility and durability.

\section{Reasserting the Party's Domination: The Project of Harmonious Society}

The project of 'building a harmonious society' gained momentum under China's former President Hu Jintao between 2002 and 2012 and is still upheld by the current leadership as a relevant political project to deal with growing social contradictions and conflicting interests while maintaining the CCP's legitimacy. Officially defined as 'a desire to reach unanimity by harmonizing various interests, synthesizing different opinions and diffusing complicated contradictions', ${ }^{4}$ its goal revolves around the idea of 'forging an authoritative, synthetic consensus among discordant social forces' (Baum, 2007, p. 8). The CCP has thus actively encouraged the spread of so-called participatory democracy, relying on polls, consultation of 'public opinion' campaigns and expert advice that make it appear as a 'mediator and a balancer' among contending interests and aspirations (Lam, 2007) and eventually enables it to appear as a 'paternalistic, superordinate authority' able to represent 'the full spectrum of "legitimate" societal interests while supressing persistently discordant ones' (Baum, 2007, p. 8).

The law has been assigned a new role in this political project, still keeping in line with its instrumental use which the $\mathrm{CCP}$ has always promoted. The idea of 'ruling according to the law' and the development of legal institutions are indeed not meant to provide citizens with a fulcrum to challenge the authority of the Party or the state, ${ }^{5}$ but rather to serve the purposes of controlling society, boosting economic development (Clarke, 2007), exerting political control over lower levels of administration (He, 2009), and building regime legitimacy for the central government (Landry, 2008; Peerenboom, 2002). Following the new 
ideology of 'harmony', the law has been seen as a means to diffuse social and economic contradictions, ease tensions, and maintain 'unity and stability'. The Party has promoted a non-contentious use of law based on mediation and compromise (encapsulated in the term 'harmonious adjudication'), and lawyers were 'forced into a role of cooperative facilitation rather than confrontational representation of their clients' interests' (Pils, 2011, p. 114). Although lawyers have been detached from the state since 1995 when the Law on Lawyers granted them a private status, the Party retains several means of control over them, the most conspicuous one being the use of the 'yearly examination' procedure to consider the renewal of lawyers' licences. This procedure has become even more drastic since 2009, and several pre-eminent human rights lawyers have been deprived of their licence to practice. Those lawyers are also commonly arrested or harassed by the police, or they simply 'disappear' while their families have to endure Party retaliation. As a consequence, "only few lawyers dare to "protect rights" while the majority are inclined to "protect the law" by insisting on adherence to its rule' (Pils, 2009a, p. 152). As Perry (2007, 2008) and Chen (2006) suggest, this has been a powerful factor of regime sustainability.

However, as exemplified by the cases studied below, the boundaries between fighting for rules implementation and rights development as well as between working for structural reproduction and regime contestation are often blurred in practice.

\section{Public Interest Litigation (PIL): The Pursuit of a Law Made by the People for the People}

PIL is relatively new to China but has grown rapidly over the last decade to become a significant and increasingly influential form of legal action. PILs were at first usually mounted by ordinary citizens who wanted to defend their rights as consumers. But starting from the second half of the 1990s, they were increasingly used by a new generation of well-trained, independently minded lawyers to promote social change (China Labour Bulletin [CLB], 2007). Lawyers were indeed encouraged by their newly gained private status as legal professionals as well as by reforms aimed at enhancing government accountability and legal protections for particular social groups (Fu, 2009). The characteristic of this kind of trial is that 'there is an ulterior motive behind such cases on the part of the lawyers, who aim at policy change through a legal process' (Fu, 2009, p. 129).

In an authoritarian regime such as China, PIL can be considered a subversive use of law due to the following three distinctive features. First, although the legal system is structured precisely to promote individual rather than collective action (Zemans, 1983, p. 692) and is consciously used by the Chinese state to enhance individual management of labour conflicts as a way to prevent collective action, legal activists use it as a way to generalize and publicize grievances. PIL seeks to link the defence of the rights of the actual victim with those of people in the same situation and thus to address issues that affect society as a whole or a specific social group. As emphasized by Richard (2012, p. 4), law becomes a 'vector of politicization' as it is recognized for its ability to convert 'a singular misfortune into a collective claim based on the invocation of superior principles of justice'.

PIL indeed embodies - and this is the second feature-a moral use of the law, as opposed to the instrumental use of the law made by the Party. It seeks to bring about sustainable legal changes so that the law better guarantees human rights, namely social and economic rights, by placing morality above material gain. Some lawyers even go as far 
as challenging the constitutionality of local laws and regulations and defending constitutional rights such as equality before the law or access to education (CLB, 2007; Fu, 2011). According to Tong Lihua, one of the most famous Chinese public interest lawyers and founder of Zhicheng Gongyi, the largest legal aid organization in China, ${ }^{6}$ PIL is aimed at promoting 'public interest law', which is defined as 'providing the disadvantaged groups with hope, confidence, and protection'. It is established to uphold and protect the lawful or legitimate interests of the 'large vulnerable majority' and is thus considered as being 'the soul of rule of law' (Tong, 2009, p. 2). His organization's goal is indeed 'to promote the spread of democracy and rule of law in China', ${ }^{7}$ but as a 'practical idealist' — as Tong likes to call himself (Tong, 2009, p. 8) — he has always been careful to garner official support and maintain a close collaborative relationship with the authorities. ${ }^{8}$ He has also been awarded numerous honours, including being selected by the central government as the sole lawyer representing the Chinese legal profession on the 'Rule of Law Float' at the National Day Parade for the 60th Anniversary Celebrations of the funding of the RPC that took place in Beijing in 2009. ${ }^{9}$ Notwithstanding Tong's own ambiguities (does he aim at fostering democracy and rule of law in the liberal sense of the terms, or does he subscribe to the idea that they can co-exist with the CCP leadership) and conspicuous manipulation on both his part and the part of the authorities, his attempt to play by the system to promote human rights, while also contesting it and acknowledging and using it, makes him a representative of moderate activist lawyers.

The third feature that makes PIL seem subversive is that it appears as an alternative means of political participation that implies a disavowal of existing institutions. In the context of an authoritarian regime where access to political representation is restricted, and where political participation and competition for political power are prohibited or even criminalized, PIL is an alternative process through which aggrieved citizens can claim their rights (Fu, 2009, 2011). It thus indirectly challenges the legitimacy of institutionalized channels of representation-such as the National People's Congress that Tong dismisses in scarcely veiled terms as controlled by a 'privileged minority' characterized by its 'lack of incentive and reluctance to reform, selfishness and greed' (Tong, 2009, p. 8) by fostering the ideal of a law made by the people for the people. PIL indeed creates a momentum for collective action that takes place at the fringe of the courts: While building strategic alliances with the media as well as people sharing the same interests and provoking public debate, public interest lawyers broaden the possibilities for the weak majority to make their claims heard and increase transparency in the law-making process. Over time, lawyers have resorted to increasingly sophisticated strategies to turn PIL into an even more significant means of political participation. As outlined by Fu and as exemplified by the case studied below, activist lawyers 'spot legal opportunities, in particular a problematic [or important] government decision, and plan subsequent legal strategies, especially identifying a proper plaintiff, to enhance the possibility of winning and maximise the impact of the case' (Fu, 2011, pp. 351-352).

Cause lawyers in China, as elsewhere, 'deploy their legal skills to challenge the prevailing distribution of political, social, economic, and legal values and resources' (Sarat \& Scheingold, 2001, p. 13) and hence assume an undeniable political role. However, they remain moderate as 'PIL aims at remedies that are politically permissible within the authoritarian system and legally enforceable by China's weak judiciary' (Fu, 2009, p. 128). The $\mathrm{Xu}$ Yange case that was fought by Zhicheng Gongyi against Kentucky Fried Chicken (KFC) in 2006 to terminate a practice known as 'workforce transfer' 
(laowu paiqian) at the same time as the national Labour Contract Law was under preparation, illustrates both the potential and limits of the Chinese PIL and provides a helpful example by which to discuss its political implications. ${ }^{10}$

'Workforce transfer' is a practice that has become pervasive among employers in China, especially among foreign firms and multinationals, to circumvent a labour law that has become more constraining over time. Workers are obliged to sign a contract with a small company (a 'cover' agency) or an employment agency that pays their salaries and contributes to social security, whereas the workers continue to work for the main enterprise. ${ }^{11}$ This practice enables the real employers to evade their social responsibilities, makes it easier for them to fire employees when they are no longer needed, and reduces compensation paid. This practice particularly affects migrant workers as the development of a universal labour law has compensated for the discrimination they used to suffer under the hukou system ${ }^{12}$ and has made the rural workforce nearly as expensive as urban workforce. According to Zhicheng Gongyi, tens of thousands of workers had fallen victim to the workforce transfer practice in China by the time the case was considered.

$\mathrm{Xu}$ Yange's grievance provided a good opportunity to denounce this practice while the Labour Contract Law was being discussed. ${ }^{13}$ The legislation could be either amended following public debate, or be accepted as it was, since the European and American Chambers of Commerce had made it known that foreign firms would pull out of China if the Labour Contract Law was to better protect workers' rights. ${ }^{14}$

$\mathrm{Xu}$ was fired after working for KFC for 11 years without a proper contract. He had, however, signed a contract with a cover agency for a year and five months, which meant that his compensation paid out by KFC was reduced by one-sixth. Zhicheng Gongyi helped $\mathrm{Xu}$ to file a complaint with the arbitration committee and transmitted the details to the press, namely to the official Communist Youth Daily, in the hope that media could trigger a public debate. The arbitration committee rejected Xu's complaint, citing the absence of a work contract with $\mathrm{KFC}$, even though he provided other evidence attesting to his work relationship with the US chain. Xu decided, with the help of Zhicheng Gongyi, to bring the matter before the court.

The first court appearance was nonetheless a failure: Xu's plea was rejected on the grounds that he was under contract with a firm other than KFC. Reacting to the court judgement, publications such as China Youth Daily and Southern Metropolis News carried articles publicizing the $\mathrm{Xu}$ Yange case and explaining how foreign firms made illegal use of workforce transfer. ${ }^{15}$ Meanwhile, the All China Federation of Trade Unions (ACFTU) accused KFC through a high-profile newspaper (the China Economic Review) of applying human rights double standards by using the workforce transfer practice exclusively for Chinese workers. ${ }^{16}$ The press thus became the arena of confrontation for experts (lawyers, academics), unions, and non-governmental organizations (NGOs), on the one hand, and KFC and the foreign chambers of commerce, on the other. Debate spilled over online, where public opinion overwhelmingly favoured $\mathrm{Xu}$ and called for scrapping the workforce transfer practice. Public opinion pressure was successful in winning Xu's case a second hearing.

KFC fought back by issuing an open letter carried by the press, claiming that its practice was in conformity with Chinese law. Zhicheng Gongyi then mounted a defence by conducting its own enquiries, drafted a report refuting point by point all of KFC's arguments, and disclosed the report during a press conference. Several newspapers published the conclusions, which included: First, Xu had been compelled to sign a contract with a cover 
agency. This contract was thus null and void, and KFC's practice was unlawful inasmuch as Xu continued to work for the US chain while being denied a proper contract. Second, $\mathrm{Xu}$ was moreover fired over a minor mistake, which occurred after he had put in overtime well above the legally authorised limit. Third, labour transfer, whose purpose is to allow one firm to escape its social responsibilities, is legally unsustainable. The agency with which $\mathrm{Xu}$ had signed the contract lacked the means to assume its social responsibilities and, as such, the case was emblematic of the misuse of 'workforce transfer' by big companies. The report also stressed that Xu's case was hardly unique, and that a considerable number of other Chinese workers were affected by this practice.

A few days later, KFC publicly acknowledged its mistakes and officially ended the labour transfer practice. $\mathrm{Xu}$ was compensated in return for abandoning plans to file an appeal at a second hearing.

Finally, the Labour Contract Law eventually included 11 articles (57-67) codifying the workforce transfer practice. Drawing on Zhicheng Gongyi's arguments, it stipulates that such transfers must take place with the worker's assent, that the firm where the worker is sent must have a minimum capital of 500,000 Yuan and set aside a reserve fund, and that in case of problems such as workplace accidents, the responsibility falls on both firms. The law also specified that the practice of transfer should only concern temporary workers for a maximum of two years, and that an employee cannot be transferred again to another post. Although the 'dispatch labour' practice has not been abolished in name, it has become more clearly codified in favour of workers, except on one count: The calculation of seniority. This issue was not tackled in the law, the possibility of creating jurisprudence on this point having been lost with the amicable settlement of Xu's case and abandonment of his plans to appeal.

This is highly regretted by Zhicheng Gongyi, which has stressed that the law's silence on the seniority issue has in a way allowed the practice to continue: The NGO has had to fight many cases similar to Xu's since then. In fact, a 2011 ACFTU survey revealed that the practice has proliferated in recent years and affected 60 million Chinese workers. ${ }^{17}$ Dispatched workers' period of employment varies from two to ten years; the temporary character of such jobs as stipulated by law is thus flouted. ${ }^{18}$ Zhicheng Gongyi underlines that only the principle of firms' responsibility for workplace accidents and the prohibition of enterprises 'dispatching' the same employee several times are somehow respected. ${ }^{19}$

This case is emblematic of the way trials now spill over beyond the courts: The mobilization was able to capture the attention of the media, muster powerful allies, ignite public debate, and force central government attention to the issue. This kind of resistance spreads rights awareness among migrant workers and nurtures a discussion over the interpretation of the law as well as a public debate over norms and values the society needs to foster. As such, it opens a democratic social space within the authoritarian regime, whose pressure compels the Party to remain somehow engaged in protecting individual rights and the common good.

However, such mobilization does not fundamentally undermine the existing structures of political domination. Rather, it reproduces the mechanisms by which power is wielded: If it indeed impacts the content of political decision, it does not affect the way it is made. By resorting to mediation and favouring the immediate and particular interests of his client over the general interest, Zhicheng Gongyi's Tong eventually paid tribute to the concept of 'harmonious adjudication'. Further legal action would have indeed represented excessive political and economic costs for the Party, which was intrinsically divided with the rallying 
of the ACFTU to the cause, would have certainly triggered a fierce backlash from foreign investors, and would not have necessarily guaranteed a better settlement for $\mathrm{Xu}$ or in terms of legal change. Such mobilization reproduces to some extent the model of public consultation fostered by the CCP as it eventually ends up providing the central government with a catalogue of propositions for law amendment on which it can draw to its liking, discarding those that are less favourable to government. As a result, the new enacted law appears as a compromise that actually continues to favour vested interests over individual rights and ethical considerations and hence fails to truly reflect the will of the majority, albeit taking it better into account.

Moreover, the ultimate goal of the mobilization-affording all agency workers the possibility of obtaining reparations and preventing recurrence of such practices-has not been realized. This is characteristic of a mobilization that does not aim at fostering the institutionalization of rights by bolstering institutions such as the legislature or the judiciary, but strives instead to compensate for their weakness and is thus doomed to be mounted endlessly anew. In fact, the practice of labour transfer has become endemic over the past few years, especially in large-scale, state-owned enterprises involved in petrochemicals, telecommunications, and finance, where an estimated two-thirds of employees are agency labour, as well as in privately owned manufacturers and public institutions. Indeed, the National People's Congress Standing Committee has drafted a series of amendments to the Labour Contract Law and submitted them for public discussion during the summer of 2012. ${ }^{20}$ The new law, which came into effect in July 2013, was nonetheless greeted with little enthusiasm-and little fear on the part of employerssince, as this whole story points out, a major plague in authoritarian regimes is the lack of law implementation. This now leads us to consider how rights defenders are mobilizing the law to try to fill the huge gap between rights granted and rights enforced.

\section{Administrative Litigation (AL): Constraining Authorities to Abide by the Law and Enhancing Government Accountability}

Although a legal right since the promulgation of the Administrative Litigation Law (ALL) in 1989, suing the state is still deemed a very sensitive legal action in China. Indeed, the law sets many limitations to both acts and administrative organs that can be challenged (the State Council for example cannot be sued). ALs have been seen as an act of sheer defiance by local authorities that usually do everything to prevent them. As precisely documented by O'Brien and Li (2005), officials commonly put pressure on Chinese citizens to discourage them from filing lawsuits as well as on the judges so that they do not accept the case, put an end to the procedure, or rule against the plaintiffs. Even when citizens emerge victorious from the courtroom, rulings are generally ignored or subverted by local governments. Moreover, retaliation - that can be as bad as imprisonment-is commonplace. Despite this, the number of cases has grown impressively from 13,006 in 1990 to 100,921 in 2001 and 136,353 in 2011 (O'Brien \& Li, 2005, p. 32; Law Yearbook of China, 2012).

Many studies have focused on the way citizens have used AL to challenge administrative decisions (O'Brien \& Li, 2005; Pils, 2009b). But it has been also widely used to compel the administration to fulfil its duty. AL has thus played a crucial role in the rights defence commitment that aims at filling the gap between the law on paper and its actual implementation (Teng, 2009, p. 125). This trend is evidenced by the citizens' 
representatives' mobilization to defend migrant workers' rights in the Pearl River Delta in the 2000s.

Chinese law provides for the possibility for agents without a lawyer license to act as legal representative in court. Citizens' representatives (gongmin daili) are generally migrant workers who learned the law by themselves through a labour dispute with their employer. In the process of protecting their own rights and helping friends and relatives, they gained a lot of legal knowledge and skills. Even though most of them are only primary-school educated, their knowledge in filing labour disputes is better than some legal professionals, who-with the notable exception of the famous labour lawyer Zhou Litai-generally consider labour disputes, especially AL, as too sensitive, lengthy, and financially unrewarding. By charging only small fees and effectively protecting the rights of many plaintiffs, citizens' representatives have acquired a good reputation among migrant workers and gained their trust. In the mid-2000s, there were a few hundreds practicing in the Pearl River Delta. I conducted interviews with one of them specialized in AL in July 2012 and April 2013. I was able to meet him in his office located in Shenzhen Bao'an district, and he gave me access to his files.

Labour inspection is almost non-existent in China, and workers often have to face problems such as non-payment of their salaries or severance pay, excessive overtime without proper compensation, no subscription to social security, etc. When workers complain to the local labour inspection bureaus, the latter often drag on unduly before accepting the case, carry out formal investigations without settling the conflict, or make administrative decisions egregiously in favour of employers. They also commonly ignore complaints and refer plaintiffs to arbitration committees, which entail processes that are notoriously lengthy, costly for complainants, and inefficient. ${ }^{21}$

Relying on the ALL but also on the Labour law (1995) and the Labour and Social Security Checks Regulation (2004), which clearly state labour administration's duty in labour law enforcement and give the right to any citizen and organization to sue administrative organs that fail to comply with the law, ${ }^{22}$ my informant widely resorted to AL during the 2000s as a way to monitor local administration in charge of labour issues. According to him, the rationale behind this was to help workers get their due more quickly than if they went through the arbitration committee/trial process, require local authorities to fulfil their duties as warrant of the public interest, and put pressure on the government so that it finds structural remedy to this situation. In the mid-2000s in the Pearl River Delta, several citizens' representatives as well as some labour NGOs I interviewed indeed held that resorting to legal proceedings was an effective way to put pressure on the state and force it to implement incremental reforms that would eventually lead to more structural change. As one informant, referring to Marx, ironically noted: 'A quantitative change can lead to a qualitative change. ${ }^{, 23}$

This practice indeed proved to be an efficient trick to momentarily break the collusion between local authorities and employers and created ad hoc checks and balances within the system. My informant filed almost 400 cases against the Shenzhen Bao'an district labour administration between 2003 and 2007 and, according to him, won 95\% of them. Based on the law files consulted, labour administration is not fined nor subject to disciplinary proceedings, but so to speak 'condemned' to fulfil its duty by thoroughly investigating the case as well as obliging employers to pay what they owe to workers and compensate them according to the law. Most of the time, labour administration would appeal against the court decision, citing the lack of evidence or quoting certain regulations to 
discard its responsibilities to social security bureaus or arbitration committees, but the second instance judgment would generally confirm the first instance judgment. The whole procedure was generally quick (a few months, which is very unusual for trials related to labour issues) and decisions fairly enforced, which is also very uncommon for this kind of trial (O'Brien \& Li, 2005).

There were two reasons for such efficacy. First, the litigant was wary about setting limits to his endeavour and collaborated with the authorities to find 'harmonious' settlements beneficial to all parties, hence minimizing the contentious component of his action. Although he sought media support for the most representative cases, he defended very few collective cases (only one-tenth of the total trials), as they are deemed sensitive and generally similar to strikes. He also refrained from demanding that administrative organs that violated the law bear the consequences. Furthermore, payments were generally sorted out through informal negotiation with the employer, the labour inspection team, the employee, and his representative under the supervision of the Labour Bureau. Such negotiation avoided that companies owing a large amount of money to their employees go bankrupt, while guaranteeing plaintiffs much better compensation than if they had gone through other channels of redress.

But the second and main reason for success was chiefly political. At that time, China's economic development was thriving, and the country was plagued with growing social inequalities and social unrest, particularly among migrant workers in the Pearl River Delta. The central government had put an absolute priority on stability maintenance, and authorities' major concern was to channel workers' grievances into legal redress in a way to address the growing number of strikes and demonstrations. As outlined by He (2009, p. 145),

when social conflicts mount and the state switches its administrative focus from one exclusively on economic development to one that pays greater attention to harmonious-society building, administrative law becomes more desirable, both because of its relatively fairer process and its cheaper oversight cost.

However, local authorities soon realized that this strategy was also unfavourable to them as these repeated administrative trials, which were widely reported by the media, undermined labour administration's image while also causing considerable economic losses to companies. When the financial crisis struck China in 2007, they forcibly put an end to the experience. On 15 March 2007, Shenzhen's Bao'an District People's Court issued internal regulations, which placed various restrictions on the ability of citizen's representatives to participate in lawsuit proceedings, namely stating that they must hold a bachelor degree in law. ${ }^{24}$ Additionally, it required that citizens' representatives and their clients appear in court to sign a statement saying that all legal work will be pro bono. Regulations were strictly enforced, and Bao' an District Courts no longer allowed people with the identity of 'citizens' representative' to participate in litigation. Shenzhen's legal and commerce departments were also united in 'cleaning up' labour disputes legal consultation services. At the height of the crisis, between late 2008 and late 2009, the arbitration committees and courts rarely accepted workers' complaints and even more rarely made judgements in their favour. ${ }^{25}$ After that, most of the citizen's agents had no choice but to cease their activity.

Their effort was however not totally in vain as a number of concrete steps were taken both at the local and national levels to remedy the situation. According to my informant, 
the number of labour inspectors greatly increased from 70 to 170 in Bao'an district. In October 2006, the Supreme Court issued a judicial interpretation on labour conflict resolution stating that workers could reclaim up to a maximum of two years' overtime payment arrears. According to my informant, while limiting the time and thus the amount that can be claimed, this statement also increases the propensity of local labour administration to apply the law to employers. Finally and more importantly, the Law on Mediation and Arbitration of Labour Disputes was passed at the end of 2007. The law speeds up the procedure for labour arbitration to a maximum of 45 days, makes it free for plaintiffs, and makes arbitration committees' rulings biding. ${ }^{26}$ Such measures can be seen as progressive but also as what they really intend to be: A way to avoid much-needed structural change. As noted by my informant, no institutional checks were created to ensure that labour administration would be compelled to fulfil its duty in the future.

This example shows how heavily the implementation of law in China is dependent upon contention or, so to speak, active participation of citizens. As demonstrated by Zemans (1983), when mobilizing the law, citizens actually become functionaries of the state by invoking its legal authority. Indeed, when resorting to AL, Chinese citizens 'use the power of the [Central] state on their own behalf' against its local representatives. In doing so, litigants and plaintiffs help the central state to enforce 'political control' (He, 2009) over the local administration and effectively participate in authoritarian governance instead of promoting the rule of law. In this paper, He distinguishes 'power control' derived from institutional checks and balances as provided by the rule of law from 'political control' derived from the use of administrative law by the central state in the Chinese authoritarian regime.

"Power control" refers to the direct and universal restraint of state power; whereas "political control" primarily refers to how one component of the state, that of upperlevel government, works to control another component of the state, that of lowerlevel government, to make sure that lower-level government indeed pursues the goals of upper-level government. (He, 2009, p. 145)

Such mobilization thus assumes a functional role in the regime's mode of operation: ${ }^{27}$ It creates ad hoc checks and balances at the expense of citizens that remain effective as long as they meet the Party's overall interests, the latter retaining the capacity to put an end to legal mobilization when costs become higher than gains. It also constrains the Party to adapt, as shown by the new policies designed to better protect migrant workers' rights within the system.

The two case studies described above show that the legal process makes citizens participants in the authoritarian governance as much as challengers of the state. Legal mobilization broadens the possibilities for challenging the Party in the context of lack of democratic participation and institutionalized political opposition. At the same time, as the practice of law-even when it takes place at the fringe of the courts and resorts to collective action-is always exercised in a political framework that is not fundamentally challenged, the political regime finds itself thereby perpetuated.

However, legal mobilization, as recalled by Zemans (1983), is not limited to direct use of state legal structures. Thus, an examination of the political role of the law must necessarily include the entire range of occurrences over which citizens 'mobilize the power of the law on their own behalf' and should not be limited to litigation per se. In fact, some public 
interest lawyers, believing that the existing legal mechanism is fundamentally biased against labour and that substantive rights are compromised by institutional design, have decided to avoid the courts and use the law as a means to empower civil society.

\section{Using Contractual Law as a Shield to Promote Collective Rights in the Workplace}

The Laowei (literally 'workers' rights defence') law firm was created in Shenzhen in July 2005 by Duan Yi, a lawyer who has been working on issues relating to labour rights for decades and who is well known for his advocacy for the right of collective bargaining. In China, where the ACFTU, which operates under the supervision of the Party, is the sole authorized union and where the right to strike is not legally granted (Chen, 2007), the law only provides for 'collective consultations': Workers are, at best, formally consulted by official trade unions during the process of establishing collective agreements. As a result, collective contracts usually are a mere replica of minimum legal requirements (Clarke et al., 2004). Moreover, the law provides no clear procedure for resolving collective labour disputes.

Having experienced the prolonged legal process in litigating labour disputes and the frustration and desperation experienced by workers, Duan Yi started in 2009 to see collective bargaining as an alternative to the legal process, which he held as inefficient and biased, and as a way to involve workers in the struggle. ${ }^{28}$ Still retaining his identity as a lawyer but holding that efficient legal mobilization should necessarily occur through the emancipation and the empowerment of the working class, he shifted his priority from litigation on individual cases to government advising and advocacy for the establishment of a genuine system of collective negotiations, 'distinct from collective consultations in that they are controlled by the workers whereas [the former] are controlled by the authorities', ${ }^{29}$ as well as training labour for industrial action. As he points out,

collective bargaining is a way to make the workers participate in the development of strategies to defend their interests, forcing them to take their destiny in hand and no longer suffer passively what companies and the authorities decided for them in terms of wages. ${ }^{30}$

His firm, together with Chinese labour NGOs, provides a package of services, ranging from training for workers and potential labour leaders who have emerged in spontaneous labour action, ${ }^{31}$ advising workers on collective bargaining with the management, mobilizing support for workers who take industrial action, and defending in court labour leaders who are punished for their participation in collective actions. The following example of the first case of collective bargaining that took place in November 2011 shows how the Laowei law firm has initiated an innovative use of law to promote social change that does not reassert the power of the authoritarian state but rather enables workers to emancipate themselves from traditional power structures, namely employers and official trade unions.

On 17 October 2011, more than 1000 workers of the Guanxing factory, a plant producing watchbands in Shenzhen, went on strike to protest against unpaid overtime, an issue that workers had been trying to raise with the management for more than a year. The dispute was about a 40-minute break marking the rotation of work teams during which workers were forced to work. The workers ended the conflict after 15 days when the 
management promised to pay them in the form of bonuses. But considering that the problem was not solved, ten workers' representatives went to the Laowei law firm with a letter signed by 584 employees asking lawyers to represent them in negotiations. The law firm signed a contract with the workers and, arguing that the negotiations would be held in accordance with the Regulations of the Shenzhen Special Economic Zone to Promote Harmonious Labour Relations, informed in writing the authorities in charge of labour, the Municipal Federation of Trade Unions, the Office of Legal Affairs as well as the Bar Association of the city of Shenzhen. None opposed. The company, which was under great pressure as work slow-down made the production rate fall by $30 \%$, agreed to mediation and hired a lawyer as well. Negotiations took place over ten days without intervention by the authorities and trade unions and focused on determining whether, from a legal point of view, the 40-minute break during which the workers had been forced to work for more than five years should be considered as working time.

Among the 12 representatives who were elected by workers, three were allowed to directly take part in the negotiations, and the others to observe. During the first round of negotiation, the two lawyers from Laowei law firm made it clear with the factory management that their role was not to make decisions-only workers could decide for themselves - but to provide a legal background for their claims. Workers indeed did not remain inactive. When the negotiations became deadlocked, workers initially refused to work overtime. Then the workers' representatives argued that if management refused to consider their request, factory workers could no longer regard them as their representatives and, therefore, they could no longer prevent workers from resuming the strike.

The strategy proved successful, as the company finally agreed to pay $70 \%$ of the accumulated overtime (on top of the bonuses already granted) to all workers, including those who initiated the movement. In return, workers' representatives committed to encouraging workers to increase their productivity to make up for losses resulting from the conflict. An agreement was duly signed under the auspices of the law firm. For its part, the factory management manifested its satisfaction regarding the negotiations outcome by inviting more than a thousand workers to a banquet. It recognized the benefits of the device developed at the initiative of workers (election of representatives, mediation by lawyers), and the desire of both parties to continue negotiating has resulted in the creation of a coordinating committee between employers and employees in the factory. Weeks after the initial agreement was signed, the committee resolved another dispute concerning overtime on weekends and its non-payment. ${ }^{32}$

This example reflects a multi-layered use of the law. First, law is used as a shield to set a community of values and goals among activists and authorities and thus protects activists from the intervention or retaliation of the authorities. Second, contractual law is used between lawyers and workers as a way to formalize their relations and thus euphemize the political dimension of workers' autonomous representation. Relying on media reports, the firm presented the experiment as a successful mediation experience benefiting both workers and their employer, ${ }^{33}$ thus publicly promoting it as a 'harmonious use of law' relying on lawyers' 'cooperative facilitation' of social conflict resolution (Pils, 2011). But in practice, it was no less than a true experience of collective bargaining: The lawyer did not act as a neutral intermediary between the two parties but instead truly represented the workers' interests against the employer, while the threat of resuming the strike if the management did not endorse a negotiated settlement indeed maintained the power balance in favour of workers. Such a non-contentious legal mobilization both allows labour law 
enforcement and seeks to advocate in favour of law amendment promoting collective bargaining by demonstrating in practice that such experiments are successful in satisfying both parties and in maintaining social stability. ${ }^{34}$ But it also directly challenges Party supervision and ACFTU monopoly over workers' representation, hence the regime's political foundations.

A few other experiences of this kind have taken place in the Pearl River Delta since then. Even though they were generally successful in settling conflicts in favour of workers, they have been faced with management and local authorities' later retaliation. A dozen worker activists were fired for 'violating the labour disciplinary code' half a year after negotiating the deal with management at the Guanxing factory. As the demands of the dismissed workers for compensation failed to win support at the arbitration committee and civil court, they prepared to appeal to the Guangdong Higher People's Court (CLB, 2012). Consequently, the Laowei law firm engaged in a judicial battle for legal protection of workers' representatives. ${ }^{35}$ In December 2012, the firm was handling at least half a dozen cases in which worker representatives were sacked, forced to resign by management, or detained by the police. ${ }^{36}$ However, the difficulties currently faced by lawyers and worker activists to get these experiments officially endorsed and institutionalized reflect the Party's will to keep them as an ad hoc mode of regulation of labour conflicts aimed at perpetuating rather than undermining the authoritarian system.

\section{Conclusion}

The three cases analysed in this article demonstrate that legal mobilization has become a new avenue for ordinary citizens to participate in both law amendment and law enforcement in China. However, these new forms of political participation take place within the authoritarian regime and should be understood as being an integral part of its mode of operation rather than a means to spread democracy and the rule of law.

The first two cases show that court-centred mobilization, albeit pushing further the limits of what is permitted and managing to momentarily disentangle economic and political interests, eventually contributes to structural reproduction. Lawyers defend rights within the existing legal system and thereby acknowledge both its legitimacy and limitations. They have indeed been careful not to favour a contentious use of law and eventually paid tribute to officially promoted 'harmonious adjudication'. PIL has become a powerful means to influence political decisions by igniting public debate and a forum where contending interests and points of view can be expressed as long as they do not challenge the state and the Party authority. In fact, decisions eventually remain uncontested and uncontestably in the hands of the Party, which has been thereby provided with a series of propositions for law amendment that it may dispose of as it wishes. Although temporarily constraining local authorities to abide by the law, AL remains a means of 'political control' to rein in the most pervasive abuses and preserve the Party's overall interests, which adequately compensates for the lack of universal and predictable 'power control'. Consequently, these two forms of legal mobilization provide ad hoc checks and balances within the system and do not advance law predictability and infallibility. Such legal mobilization nonetheless opens up a democratic space that puts pressure on the Party so that it constantly adapts and maintains its legitimacy, hence explaining the regime's durability. 
The third case study, however, shows how non court-centred legal mobilization has become a fulcrum for indirectly challenging principles of authoritarian governance. While mobilizing law to 'empower civil society' and advance social innovation, lawyers seek to promote 'social jurisprudence' - that is, to foster legal change by demonstrating that new social experiences work in practice- and indeed sow the seeds of democratic governance. Extra-judicial advocacy shares some patterns with intra-judicial advocacy, both being grounded on an assumed community of values and goals shared with the Party-State (building a harmonious society, promoting social justice by accommodating all parties, and avoiding confrontation). But extra-judicial advocacy also differs to the extent that it subverts the framework imposed by the Party for rights defence and rights advocacy and seeks to promote the institutionalization of substantive rights (autonomous organization and representation) instead of the mere expansion of formal rights (amendment of labour law). By seeking to promote socio-political change before legal change, it also grounds its persuasiveness on pragmatism rather than idealism - that is, higher principles of justice-while at the same time advocating for much more fundamental legal and political changes. However, it eventually remains dependent on court-centred, top-down legal reform. For the time being at least, the process of actual rights expansion still stumbles over the government's refusal to bestow legal protection for workers representatives, which underscores the Party's will to keep these experiments as an ad hoc mode of regulation of labour conflicts.

\section{Notes}

1. Xu was sentenced to four years in prison.

2. On the debates sparked among activist lawyers by radical actions, see Pils (2009b).

3. In their paper, Fu and Cullen (2008) distinguish 'moderate lawyers', who 'are legalistic and place more faith in the judiciary than it deserves', from 'critical lawyers' who are highly critical of the judiciary and the regime as a whole but endeavour to work through the system as they 'recognize the lack of viable alternative'. For the sake of simplification, we here use the term 'moderate lawyers' to speak about critical lawyers as opposed to radical lawyers, as Fu does elsewhere as well (Fu, 2011).

4. People's Daily (Overseas Edition), 23 March 2005.

5. For example, China's courts are not allowed to consider challenges to government actions on Constitutional grounds.

6. Zhicheng Gongyi (or Zhicheng Public Interest Lawyers) is an umbrella organization that includes the Beijing Migrant Worker's Legal Aid and Research Centre, the Beijing Children's Legal Aid and Research Centre, and the Beijing Rural Areas Rule of Law Research Centre. It provides free legal aid to children, migrant workers, criminal suspects, and criminal victims who would otherwise be unable to afford legal expertise. It is deeply entrenched into the system, as it is one of the few social organizations directly registered with the Ministry of Civil Affairs and benefits from many high-ranking protections. http://www.zcpi.org (accessed 17 July 2014).

7. http://www.zcpi.org/a/AboutUs/ (accessed 17 July 2014).

8. For a list of these official supporters, ranging from the Ministry of Justice, the China Legal Foundation, the Central as well as Beijing Youth League that Tong cautiously showcases/displays (the idea is that he tries to protect himself by hiding behind these references), see Tong (2009, pp. 6-7). By the time of my first interview with Zhicheng Gongyi in May 2010, the organization had established 18 legal aid offices supporting migrant workers in 17 provinces; all were affiliated with official trade unions.

9. http://www.zcpi.org/a/Awards/140.html (accessed 17 July 2014).

10. A detailed account of the case can be found in Tong (2009, pp. 365-396). The following information also stems from two interviews with Zhicheng Gongyi lawyers conducted in Beijing in June 2010 and July 2011.

11. However, as cover agencies are usually small and precarious, many fail to contribute to employees' social security and are unable to meet hospitalization costs in case of accidents at work. 
12. The hukou is a residency system set in the Maoist era that strictly separated the cities from the countryside and granted rights to urbanites that were denied to rural people. Since the reforms launched in the 1980s, peasants were allowed to migrate into the cities but retained their inferior status, hence forming a pool of cheap labour that played a crucial role in China's economic development. Although still in force today, the discriminatory impact of the hukou system has nonetheless been eased by the incremental development of social and economic rights.

13. On 20 March 2006, the Standing committee of the National People's Congress widely circulated the draft law to seek public feedback and advice from specialists. Public consultations, relying mainly on the Internet, have become a common practice before passing important laws.

14. http://www.business-humanrights.org/Links/Repository/785039; http://www.clb.org.hk/en/content/disp utes-over-new-labour-contract-law-foreign-business-groups-threaten-withdraw-investments (accessed 17 July 2014).

15. See for example Kendeji citui 11 nian lao yuangong jujue chengzhen cunzai laodong guanxi [KFC dismisses an employee who has been working for the firm for 11 years and refuses to acknowledge labour relation], Zhongguo Qingnianbao [China Youth Daily], 13 May 2006.

16. Quanzong guanyuan piping qiye: laodong yonggong gao shuang zhong biaozhun [ACFTU official attacks firm's double standards towards its workers], Zhongguo Jingji Zhoukan (China Economic Review), 5 June 2006.

17. http://www.eeo.com.cn/eeo/jjgcb/2011/02/28/194384.shtml (accessed 17 July 2014).

18. Pan Yi, Deng Yunxue, Laowu paiqian zhidu jinxing shi [When the reform of the delegation system is adopted], Nanfang chuang, 10 April 2011, http://www.nfcmag.com/articles/2744 (accessed 17 July 2014).

19. Interview of the author with Zhicheng Gongyi lawyers, July 2011.

20. http://www.clb.org.hk/en/content/debate-revisions-labour-contract-law-delayed-because-deluge-submiss ions (accessed 17 July 2014).

21. According to a survey conducted by a Beijing NGO in 2005 among 8000 migrant workers in 8 provinces of China, in order to recover 1000 Yuan of back-wages, complainants had to spend a minimum of 920 Yuan and devote 11-21 days to the case, which is equivalent to a loss of salary of between 550 and 1050 Yuan (Tong, 2009, p. 22). According to statistics of the Beijing municipality Legal aid center for migrant workers, among the 466 cases dealt with by arbitration city committees in two years, only $2.6 \%$ had a satisfactory outcome (Tong, 2009, p. 218).

22. Labour and social security checks regulation, art.12.

23. Author's interview with the leader of a labour NGO, December 2004.

24. Transmitted to the author by the informant. National laws, either the Code of civil procedure or the Administrative Litigation Law, nonetheless leave great latitude to local courts in authorizing citizens' representatives.

25. Interviews of the author with labour NGOs in the Pearl River Delta, April and November 2009.

26. The increased recourse to AL as a means to settle labour issues can certainly not be considered as the sole factor that pushed the central government to pass this law. The operation mode of arbitration committees was namely under Chinese NGOs' attack for long. However, it can undoubtedly be considered as one among others.

27. The analysis here joins that of Lewis (2013) on the role of NGOs in China.

28. Author's interview with Duan Yi, November 2011.

29. Qing W., Mosuo Zhongguo laogong weiquan xin moshi de Guangdong laoweisuo [The Laowei looking for a new model to defend Chinese workers' human rights], Caixing, 31 January 2012 (http://news.qq. com/a/20120131/000599.htm (accessed 17 July 2014)).

30. Idem and author's interview with Duan Yi, November 2011. The following information also stems from interviews with several lawyers from Laowei law firm in November 2011, July 2012, and May 2013.

31. Sixty training sessions were held in 2010-2011, which benefited 2800 people. Guangdong laowei lüshi shiwusuo jianjie (presentation brochure of the Laowei Law firm remitted to the author, November 2011).

32. Xitiecheng Shenzhen dai gongchang bagong shimo [The whole story about the strike in a supplier in Shenzhen Xitiecheng district], http://china.caixin.com/2011-11-24/100331010.html (accessed 17 July 2014); Yici chuncui de shichang xingwei-Shenzhen shi Shajin Huanpu Guanxing jingmi biaolian chang laozi tanpan [A pure market behaviour-Collective bargaining between management and employees at Guanxin factory in Shenzhen Shajin Huanpu district], www.jttp.cn/a/report/news/labor/2011/1122/2263. html (accessed 17 July 2014); Cong Guanxing chang shijian kan gongzi jiti tanpan—Duan lüshi zhuanfang 
[Looking at wage collective bargaining from Guanxing factory event—Special interview of lawyer Duan], Zhongguo gongren (Chinese workers), 2012, no. 5.

33. See note 32 .

34. In China, new laws generally reflect de facto social change.

35. Interviews of the author with Laowei law firm lawyers, May 2013.

36. China Labour Bulletin, 'Protecting workers' representatives' http://www.clb.org.hk/en/content/prote cting-workers\%E2\%80\%99-representatives (accessed 17 July 2014).

\section{References}

Baum, R. (2007) [The limits of 'authoritarian resilience', lecture given at CERI, Paris, January 17, 2007]. Available at http://www.stephen-t.com/pdf/the\%20limits\%20of\%20authoritarian\%20resilience\%20-\%20Baum. pdf (accessed 17 July 2014).

Chen, X. (2006) The difficult road for rights advocacy an unpredictable future for the development of the rule of law in China, Transnational Law \& Contemporary Problems, 16(1), pp. 221-251.

Chen, F. (2007) Individual rights and collective rights: Labor's predicament in China, Communist and Post-communist Studies, 40(1), pp. 59-79.

China Labour Bulletin (CLB). (2007) [Public Interest Litigation in China: A New Force for Social Justice]. Research Report. Available at www.clb.org.hk (accessed 17 July 2014).

China Labour Bulletin (CLB). (2012) [The Hengbao Jewellery Dispute]. Available at http://www.clb.org.hk/en/ sites/default/files/File/The\%20Hengbao\%20Jewellery\%20dispute.pdf (accessed 17 July 2014).

Clarke, D. C. (2007) The Chinese legal system since 1995, The China Quarterly, 191, pp. 555-566. doi:10.1017/ S0305741007001567

Clarke, S., Lee, C. H. \& Li, Q. (2004) Collective consultation and industrial relations in China, British Journal of Industrial Relations, 42(2), pp. 235-254.

Dabène, O., Geisser, V. \& Massardier, G. (Eds) (2008) Autoritarismes démocratiques et démocraties autoritaires: Convergences Nord-Sud [Democratic authoritarianisms and authoritarian democracies. NorthSouth convergence] (Paris: La Découverte).

Diamant, N. J., Lubman, S. B., \& O’Brien, K. J. (Eds) (2005) Engaging the Law in China. State, Society and Possibilities for Justice (Stanford: Stanford University Press).

Fu, H. (2009) Developing rule of law through public interest litigation, in: S. Mosher \& P. Poon (Eds) A Sword and a Shield: China's Human Rights Lawyers, pp. 129-140 (Hong Kong: China Human Rights Lawyers Concern Group).

Fu, H. (2011) Challenging authoritarianism through law: Potentials and limits, National Taiwan University Law Review, 6(1), pp. 339-365.

Fu, H. \& Cullen, R. (2008) Weiquan (rights protection) lawyering in an authoritarian state: Building a culture of public-interest lawyering, The China Journal, (59), pp. 111-127. Available at http://www.jstor.org/ discover $/ 10.2307 / 20066382$ ?uid=3738176\&uid=2129\&uid=2\&uid=70\&uid=4\&sid=21104518045603

He, X. (2009) Administrative Law as a mechanism for political control in contemporary China, in: S. Balme \& M. W. Dowle (Eds) Building Constitutionalism in China, pp. 143-161 (New-York: Palgrave Macmillan).

Lam, W. W.-L. (2007) Chinks in the Armour of the Hu Jintao administration: Can a harmonious society emerge in the absence of political reform?, China Perspectives, (3), pp. 4-11. Available at http://chinaperspectives. revues.org/1963?file $=1$ (accessed 18 July 2014).

Landry, P. (2008) The institutional diffusion of courts in China: Evidence from survey data, in: T. Ginsburg \& T. Moustafa (Eds) Rule By Law. The Politics of Courts in Authoritarian Regimes, pp. 207-234 (Cambridge: Cambridge University Press).

Lazarus-Black, M. \& Hirsh, S. F. (Eds) (1994) Contested States: Law, Hegemony and Resistance (New York: Routledge).

Lewis, D. (2013) Civil society and the authoritarian state: Cooperation, contestation and discourse, Journal of Civil Society, 9(3), pp. 325-340.

McCann, M. W. (1994) Rights at Work. Pay Equity Reform and the Politics of Legal Mobilization (Chicago: The University of Chicago Press).

O'Brien, K. \& Li, L. (2005) Suing the local state: Administrative litigation in rural China, in: N. J. Diamant, S. B. Lubman \& K. O'Brien (Eds) Engaging the Law in China. State, Society, and Possibilities for Justice, pp. 31-53 (Stanford: Stanford University Press). 
Peerenboom, R. P. (2002) China Long March Toward Rule of Law (Cambridge: Cambridge University Press).

Perry, E. J. (2007) Studying Chinese politics: Farewell to revolution? The China Journal, (57), pp. 1-22. Available at http://www.jstor.org/discover/10.2307/20066239?uid=3738176\&uid=2129\&uid=2\&uid=70\&uid= $4 \&$ sid $=21104518045603$

Perry, E. J. (2008) Chinese conceptions of 'rights': From Mencius to Mao—and now, Perspectives on Politics, $6(1)$, pp. 37-50.

Pils, E. (2009a) The dislocation of the Chinese human rights movement, in: S. Mosher \& P. Poon (Eds) A Sword and a Shield: China's Human Rights Lawyers, pp. 141-159 (Hong Kong: China Human Rights Lawyers Concern Group).

Pils, E. (2009b) Rights activism in China: The case of lawyer Gao Zhisheng, in: S. Balme \& M. W. Dowle (Eds) Building Constitutionalism in China, pp. 243-260 (New York: Palgrave Macmillan).

Pils, E. (2011) Law as conscious resistance. Chinese weiquan lawyers' experience, in: J. P. Béja (Eds) The Impact of China 1989 Massacre, pp. 109-124 (London: Routledge).

Richard, H. (2012) S'opposer par le droit: vulgarisation et usages politiques du droit de la copropriété en Russie postcommuniste [Opposing oneself through law: Popularization and political uses of condominium law in post-communist Russia], Critique Internationale, 55(2), pp. 35-50.

Sarat, A. \& Scheingold, S. (2001) State transformation, globalization and the possibility of cause lawyering, in: A. Sarat \& S. Scheingold (Eds) Cause Lawyering and the State in Global Era, pp. 3-31 (Oxford: Oxford University Press).

Teng, B. (2009) What is rights defence?, in: S. Mosher \& P. Poon (Eds) A Sword and a Shield: China's Human Rights Lawyers, pp. 122-128 (Hong Kong: China Human Rights Lawyers Concern Group).

Tong, L. (2009) Weile zhengyi [Strive for Justice] (Beijing: Falü chubanshe).

Zemans, F. K. (1983) Legal mobilization: The neglected role of the law in the political system, The American Political Science Review, 77(3), pp. 690-703.

Zhongguo Falü Nianjian [Law Year Book of China]. (2012) (Beijing: Zhongguo Falü Nanjian She). 